\title{
Lawrence novel "Rainbow" Interpretation of the thinking and behavior of the characters
}

\author{
Yan QIN \\ Nanyang Medical College \\ Nanyang,473058 China
}

\begin{abstract}
This paper tries through emotional life novel "Rainbow" to describe exploration Lawrence thought of selftranscendence. Marriage does not become an obstacle towards the other side of the world: the couple should accept each other's strange boldly factor, and maintain their relatively independence, and keep a balanced and harmonious relation. The key of self-transcendence lies on self itself, purifying the mind can help people further move towards a successful life and eternity.
\end{abstract}

Keywords- D・H・Lawrence; "Rainbow"; the thoughts of the characters.

\section{INTRODUCTION}

May 1914, the British modern writer Lawrence D • H • after seven drafts announced that he has completed the novel "The Rainbow" creation. However, this sign of maturity Lawrence works are banned immediately after publication. At that time, the official, most of the critics and the majority of the readers lambasted Lawrence because he deals directly with "sex" on this sensitive matter. In today's world of "sex" is no longer considered a scourge. Lawrence has also been accepted by the reader. Novel "Rainbow" Lawrence embodies many important ideas and concepts. I tried on the original banned book "The Rainbow", and readers discuss Lawrence's self-improvement and self-transcendence think this important phase in the "Rainbow" at the end, D • H • Lawrence Brown Winchester's third-generation representative of Ecuador Sula struggle summarize:" it is naked like a real effort to tie Jen freely under the new root, and create a new understanding of the eternal in the changes over time " "She would roots in the days of a newborn, her naked body will lie in the new sky, a new air. "Recurring" new "clearly has its unique importance. It tells the reader soil Ursula Raza root unlike her grandparents, and even different from her parents' generation and her understanding as well. From the novel, we learn that: Ursula marriage relationship has not been established with any of a male. Therefore, individual plants grow new roots only. Seen, compared with her grandparents, parents' generation, she has her own unique way of life. Ursula also realized: She and Sikelibin Chomsky there is a "gap." She also realized: the earth's crust has a "crack", "free place between her and the earth's crust." Thus, in terms of how to deal with the relationship between the individual and society, between individuals of the opposite sex, etc., are also very different understanding of her with her grandparents, parents' generation. To Ursula type figure, Lawrence obvious agrees with it. So, what Ursula fighting spirit is? The difference between her and grandparents specifically, and the parents' generation, what is? The beginning of the novel, Lawrence of "blending" word to emphasize Bronwyn family closely associated with land links. Then, Lawrence tells us that the cracks began to appear between the sexes. Men toil on the land. "Life in the vitality so that they, and not the lack of money." "But what women think about is another kind of life, and this blend of blood does not matter, she stands and overlooks the city where there is a world power. Don't care what blood bond, but go out and discover things from afar. "

\section{CHARACTER ANALYSIS IN LAWRENCE NOVEL "RAINBOW"}

For conflict sexes, Lawrence himself did not make it clear that he stood on which stand, he was just the put men and women in a particular background, let this conflict continue to develop. Beginning of the story, Lawrence tells us that: At the time, society is changing. "Masi grassy meadow on the repair from a canal ...... canal there and opened a coal mine." This change of Bronwyn family impacts the life of Brown. Brown Winchester has four sons and two daughters. Son early make a living at sea, and never come back; two sons spent a factory in Nottingham as a designer; three sons took over the slaughter thing. As for the two daughters, Eldest married a miner, second daughter stood by Boudoir inside. Youngest son, Tom, "is very sensitive to the feeling, and is also very sensitive to the surrounding atmosphere." After the death of his father, as the only Bronwyn people stay on the farm "Responsible management of farmland falls on his shoulders." Since he unlike other Bronwyn family nature, and in this particular period of social change, but also in the farmhouse "across the civilized world," he knows how: To improve themselves, beyond the self, he can not tread the footsteps of the ancestors, grandparents traveling on the route prescribed. He had to rely on his own experience, and gropes forward.

Well, why can Tom and Lydia ultimately live a happy marriage? After reading through the entire novel, we can find some tips why they live in harmony. The most important tip 
is: boldly accept each other's strange factor. As we've already mentioned: At the beginning of the marriage, this young couple had strained relations between the two sides want to impose their will and ideas. Slowly, they also realized that the dangerous of the desire of possession and domination. The result: "This couple also tune up." Excludes natural harmony between the two sides of the interference it matter, their marriage further improve the self. "They stepped into another existence range of the door ...... they crossed the doorway into the wider world ......." Lawrence also stressed out: boldly accept each other's strange factors including telepathic communication between each other to this point.

If you say, Tom and Lydia's early marriage is battle style, Will and Anna's marriage is a war-like. Anna that time, from the family bondage, the only way to expand the experience of experience can only be marriage. As she received some education, seen some of the world, she believes, is good enough for her local lad. At this point, cousin Will shows in her circle, the first meet made Anna felt that: "some strange things into her inner world, which is one hundred percent of the strange things, like her is not the last to know. "Gradually, Anna felt:." Yes, he removed her experience in the industry, he is a hole in the wall on the wall, through this hole, and she saw a bright hot sun outside world. "So she tried to marriage this way, to get rid of the dull atmosphere that familiar farm Masi breathtaking to further improve themselves, beyond the self. However, Anna in girlhood "does not believe in herself, and does not believe the world around them." "In this world, she often felt overwhelmed." He first appeared in the novel, and Lawrence described him like this, "this strange head reminded her of what, yes, an animal, a mysterious animal." Moreover, this animal is "in the tree cover in the dark." Lawrence also specifically to premarital Will described as "cats," "Eagle" Will marriage as "tiger", "lion." Clearly, Anna, Will lack Tom, Lydia a have self-confidence and a generous heart. Tom Battle, between Lydia is to understand those factors and the unknown stranger things. Anna fought, between Will it because of their anger or hostility attitude cause all its wonderful to happen. Fight against fierce strike, endless, irreconcilable. Non-separation of the two sides can not be a victory or defeat. Early in their honeymoon, they were blind to Lawrence Shen sensual wine in a negative and critical of the behavior. He put them in contact with a dark piece: "As far as the world's two seeds in the dark."

Not the kind of sensual behavior is a direct cause of the battle. Anna's too strong independence and Will's weak dependence is the main reason for the war. Lawrence wrote, "When Anna ready to open a tea party, and his heart sank, and he wants to keep the original look, isolated forever sever ties with it." More than that, he always obeys Anna, and Anna Bong is for imperial discourse, not with Anna evenly divided. Anna even just put him as appendages. In this war, Anna is the winner. But Anna is also the loser. Her victory, her freedom comes through slavery by and uniforms Will.

Anna symbolic victory in Namur nude dance scene, Lawrence wrote: "she wants to use dance to snub him, she wants to jump her jis God, before God, she pressed him a head." However, the victory did not bring her happiness, she felt lonely and desolate instead. The responsibility of all to blame Will this war, or all the blame Anna, while he or she is meaningless accusations. Conflict between husband and wife could have been inevitable, but can not quite put it as a bad thing. Tom and Lydia, this couple is slowly matured in the conflict and improve themselves in conflict. The key question is: how to treat, handle conflicts this phenomenon. Anna from childhood formed a strong personality. This decision is difficult to abandon her ego deficiencies. And Will is a shadow of the wildly follow Anna rpm. This overdependence is also difficult to determine his selfimprovement. The two sides continue to blame the other side for their own limits and recriminations. They both have failed as a parent's generation, as the first spiritual communication, and then maintain their relatively independence.

It goes without saying that our answer to the above question is in the negative: Anna and Will have failed to show a complete self. Not to mention self-transcendence. Possessiveness and lack both assertive and less like too much, it can not communicate with the soul. Independent self is a prerequisite for spiritual communication. Pure sensual is obstacle for achieving this goal of self. The first three generations of Ursula's fighting spirit and ancestry are not unrelated. Her early novels beginning with the desire wife Bronwyn roughly the same desire: to go out and be educated to attractive place to travel adventure. She is better than other women in Bronwyn, and she left home to the known physical world which has been explored and she found that it was not her dream the other side of the world. Influenced by their family of women, men are also taken Brown Winchester house, into the community. Tom became a gentleman grandfather, Will is also out of the house, and became art teacher, uncle Tom from providers. But men and women have not been able to find answers to questions raised by the beginning of the novel. Namely: "Why learn a distant country will make a person's life becomes different from others, better than others, more powerful then why people can much more than pigs and cattle for their services?"

Re-emergence of first love Sikelibin Chomsky reminded her of the "the first morning light." She thought, "He will open her vast area, the vast open expanse of self-realization, always happy space." When Ursula was both isolated and blind, and naturally, she once again invest Sikelibin Sharansky. Several disappointing experiences have made Ursula mature a lot. Although this is her Sikelibin Chomsky were reunited for the first time after six years, she also vaguely aware of:. "They are hostile to both sides," she still picks Sikelibin Sharansky. His handsome looks fascinated her. Slowly, she is aware that Sikelibin Sharansky lack soul. But she still clings tightly, because Sikelibin Chomsky can be met on her flesh. So far, Ursula still poles apart to achieve farther on the road of self: she has always ignored this point: I myself deep inner world. She has not yet realized: When she was away from home into the world precisely because of her inner world is not peaceful, her restless soul.

Obviously, Lawrence hinted to us, to break away from home the fact that the world does not mean that the goal of self-realization has been reached. 
Salim uncle that is a typical example: He finally connected with a mechanical thinking. Sharansky Sikelibin Ursula dependence makes her repeatedly disappointed. Finally, she flatly rejected his proposal. The new tests come again her head: she had found pregnant. Her heart was very contradictory: "Her body was moved to the waves of war millet, mentally very depressed." Body and Soul are in fierce fighting. She once wanted: being a wife and mother forget. Exactly two weeks later, she suddenly be enlightened: Sharansky Sikelibin flesh does not help her selfimprovement, better ourselves. "Rusting piece of her mind about the things Sikelibin Chomsky has been burned to ashes." (P595) As a result, "she lifted her head and looking ahead, Sikelibin Sharansky gone."

\section{CONCLUSIONS:}

She decided to continue to explore the true meaning of life. This time, Ursula last journey in search of eternal life found a new starting point. She knows that the search direction from the known to the unknown material world tangible and intangible spiritual world. This is a qualitative leap in the process of understanding. At this time Ursula has slowly move closer to the other world. In recognition of the degree, she has exceeded her grandfather and grandmother, but also over her mother and father. She has recognized the limitations of physical and material world. Although Ursula now have a clear goal, and her rugged road ahead will be tortuous, but she convinced: the future will be bright. "For this new dawn, how long had she fight against dust and dim fighting? She felt how fragile, how thin, how clear, like delicate flowers open in late winter. However, the darkness has passed, the dawn is coming. "Ursula has exhausted still definitely the heart: tenaciously go, do not reach the goal, dogged. Lawrence praising Ursula precisely because in the pursuit of self-improvement and self-transcendence in this process have perseverance and indomitable spirit. In summary, we have been in self-improvement is not difficult to see that Lawrence novel "Rainbow" wanted to express the idea of self-transcendence is:

Marriage does not become an obstacle towards the other side of the world. Sexes combined, if the husband and wife can properly handle the relationship will help each other towards self-improvement and self-transcendence in this direction was taken bigger, faster pace. On the contrary, it plays them back. However, to achieve self-realization and self beyond this goal, dominant, a key role is the self itself, is not a foreign object. All foreign objects can play a role in only one co-edge only. Only firstly complete selfpurification of the soul, can people further maintain the vitality of life, and finally reach a successful life and eternity.

\section{References:}

[1] Peter Widdowson (ed) DH Lawrence (Longman Group UK limited 1992) P2.

[2] Shi Lei. Translation: "Rainbow Dust off the muddy" on behalf of Translator, Lijiang Publishing House, August 1992 edition, P3.

[3] Duane Edwards, The Rainbow, A search for New life (GK Hall Co. 1990) P.16 